\title{
Level of environmental threat posed by horticultural trade in Cactaceae
}

\author{
Ana Novoa, ${ }^{1,2 *}$ Johannes J. Le Roux, ${ }^{1}$ David M. Richardson, ${ }^{1}$ and John R.U. Wilson ${ }^{1,2}$ \\ ${ }^{1}$ Department of Botany and Zoology, Centre for Invasion Biology, Stellenbosch University, Matieland, South Africa \\ ${ }^{2}$ Invasive Species Programme, South African National Biodiversity Institute, Kirstenbosch Research Centre, Claremont, South Africa
}

\begin{abstract}
Ornamental borticulture has been identified as an important threat to plant biodiversity and is a major pathway for plant invasions worldwide. In this context, the family Cactaceae is particularly challenging because it is considered the fifth most threatened large taxonomic group in the world; several species are among the most widespread and damaging invasive species; and Cactaceae is one of the most popular borticultural plant groups. Based on the Convention on International Trade in Endangered Species of Wild Flora and Fauna and the 11 largest online auction sites selling cacti, we documented the international cactus trade. To provide an in-depth look at the dynamics of the industry, we surveyed the businesses involved in the cactus trade in South Africa (a botspot of cactus trade and invasions). We purchased seeds of every available species and used DNA barcoding to identify species to the genus level. Although $<20 \%$ of this trade involved threatened species and $<3 \%$ involved known invasive species, many species were identified by a common name. However, only $0.02 \%$ of the globally traded cacti were collected from wild populations. Despite a large commercial network, all South African imports (of which 15\% and 1.5\% were of species listed as threatened and invasive, respectively) came from the same source. With DNA barcoding, we identified $24 \%$ of the species to genus level. Based on our results, we believe that if trade restrictions are placed on the small proportion of cacti that are invasive and there is no major increase in harvesting of native populations, then the commercial trade in cactus poses a negligible environmental threat. However, there are currently no effective methods for easily identifying which cacti are traded, and both the illicit harvesting of cacti from the wild and the informal trade in invasive taxa pose on-going conservation challenges.
\end{abstract}

Keywords: alien species, biological invasions, cactus, DNA barcoding, e-trade, introduction pathways, invasive plants, nursery, ornamental plants

El Nivel de Amenaza Ambiental que Representa el Mercado Horticultor de Cactáceas

Resumen: La borticultura ornamental ha sido identificada como una amenaza importante para la diversidad de plantas y la principal vía de introducción de plantas invasoras a nivel mundial. En este contexto, la familia Cactaceae es particularmente complicada ya que está considerada como el quinto grupo taxonómico más amenazado en el mundo; varias especies en la familia se encuentran entre las especies invasoras más dañinas; y esta familia es uno de los grupos botánicos más populares en la borticultura. En este estudio, documentamos el mercado internacional de cactus, basándonos en la Convención sobre el Mercado Internacional de Especies en Peligro de Flora y Fauna Silvestre y en los once sitios en línea más grandes dedicados a la venta de cactus. Para proporcionar una mirada profunda a las dinámicas de la industria, realizamos censos sobre los negocios involucrados en el mercado de cactus en Sudáfrica (un punto caliente del mercado e invasiones de cactus). Compramos semillas de cada especie disponible y utilizamos el código de barras del ADN para identificar a las especies hasta el nivel de género. Aunque $<20 \%$ de este mercado involucra a especies amenazadas $y<3 \%$ involucra a especies invasoras conocidas, muchas especies fueron identificadas por un nombre común. Sin embargo, sólo el $0.02 \%$ de los cactus vendidos a nivel global fueron recolectados de poblaciones silvestres. A pesar de una gran red comercial, todas las importaciones sudafricanas (de las cuales el 15\% y el 1.5\% fueron especies enlistadas como amenazadas e invasoras, respectivamente) provinieron de un misma fuente. Con el código de barras del ADN, identificamos a $24 \%$ de las especies hasta el nivel de género. 
Con base en nuestros resultados, creemos que si las restricciones del mercado se colocan sobre la pequeña proporción de cactus que son invasores y no bay un mayor incremento en la cosecha de poblaciones nativas, entonces el mercado comercial de cactus plantea una amenaza ambiental trivial. Sin embargo, actualmente no hay métodos efectivos para identificar fácilmente cuáles cactus son vendidos, y tanto la cosecha ilícita de cactus silvestres y el mercado informal de taxones invasores presentan retos continuos para la conservación.

Palabras Clave: cactus, código de barras de ADN, especies foráneas, invasiones biológicas, mercado en línea, plantas invasoras, plantas ornamentales, vías de introducción, vivero

\section{Introduction}

Humans have been cultivating plants for ornamental purposes for millennia. The Egyptians cultivated lily of the valley (Convallaria majalis) from as early as the 10th century BC, and the common garden peony (Paeonia lactiflora) was grown in China in the 8th century BC (Zhou 1994). During the last few centuries, however, the increasing demand for novelty in color, design, and use have encouraged collectors and gardeners to search for ornamental plants previously unknown in their regions. For example, in the early 1600s, the Englishman Sir Robert Cecil sent his gardener John Tradescant out of Europe to search for new ornamental species (Reichard $\&$ White 2001). Plant exploration soon became very popular, and by the 18th century almost 9000 ornamental plant species had been introduced to the British Isles from all parts of the world (Clement \& Foster 1994). The first botanical garden in the United States was established in 1747 in Portsmouth, New Hampshire (Ewan 1969), and in the 1800s nurseries began to carry large stocks of non-native (mostly European) ornamental plants (Wyman 1968). The horticultural industry is now large (e.g., US\$11 billion/year in the United States [Heywood 2001]), but in most countries it is based chiefly on species that are non-native to the targeted market (Reichard \& White 2001). Although breeders are creating new cultivars of existing ornamental taxa (Callaway \& Callaway 2000), collectors are still looking for new potential ornamental plants in the wild around the world (Seaton et al. 2014). The demand for new ornamental plant taxa (Phelps \& Webb 2015) has two potentially major negative consequences: it can pose a threat to the conservation of plant species through overharvesting and lead to the dissemination of potentially invasive species.

Intense harvesting of native wild populations for ornamental purposes has led to several plant species being threatened with extinction (Winter \& Botha 1994). To combat this threat, the Convention on the International Trade in Endangered Species of Wild Flora and Fauna (CITES) regulates the international trade of more than 30000 species of plants (most of which are used as ornamentals) (Reeve 2014). The imports and exports of regulated species among the signatory parties of CITES have to be authorized through a licensing system. Exporting enterprises must submit annual reports to CITES that provide information on all permits and certificates granted. All trade data included in these reports are stored in the CITES Trade Database (CTD) (http://www.unep-wcmc-apps.org/citestrade/). Unfortunately, not all exports and imports of ornamental plants go through this process, which suggests the horticultural trade of threatened plants is not effectively regulated (Sajeva et al. 2013).

Ornamental horticulture is also a major pathway for plant invasions worldwide (Reichard \& White 2001). Plant collectors, breeders, traders, and consumers often select ornamental plants that are "good garden subjects" (Dehnen-Schmutz et al. 2007a). Species traits that make plants good garden subjects are often, however, associated with invasion potential (e.g., drought and frost tolerance or high germination and growth rates) (Anderson et al. 2006). Moreover, the nature of the trade and gardening itself (i.e. repeated introductions to multiple sites across the landscape, with provision of resources to allow mature plants to flourish) act to increase the propagule pressure and opportunities for invasion (Lockwood et al. 2005; Dehnen-Schmutz et al. 2007b). Plant invasions from the horticultural trade (e.g., Carpobrotus edulis [Novoa \& González 2014], Eichbornia crassipes [Villamagna \& Murphy 2010], Lantana camara [Sharma et al. 2005]) have had a wide range of negative impacts, including high economic costs, changes in soil characteristics, and reductions in genetic diversity (Niemiera \& Von Holle 2009). Yet, the horticultural trade of invasive and potentially invasive plants continues (DehnenSchmutz \& Touza 2008; Humair et al. 2015), which suggests the regulation of the introduction, exchange, and release of invasive and potentially invasive ornamental plants remains inadequate (Burt et al. 2007).

The family Cactaceae is of particular interest because the horticultural trade in cacti has the potential to lead to the overexploitation of threatened native populations and to the spread of invasive species. The family comprises 1922 species (Novoa et al. 2015a) distributed throughout the Americas in a wide range of ecosystems, from hot deserts to high alpine steppes and tropical rain forests (Barthlott \& Hunt 1993), that correspond necessarily to morphological diversity (Anderson 2001). Due to their diversity, easy maintenance, and beauty, cacti were among the first plants exported from America by European explorers in the $15^{\text {th }}$ century (Howard \& Touw 
1981). Several different cactus species were soon found in collections and gardens, and horticulturists' interest in them has continued unabated since (Anderson 2001). More than 20 journals and hundreds of societies, socialmedia sites, and groups around the world specialize in Cactaceae (Novoa et al. 2015a). More than one-third of species in the family ( 674 species) are formally recorded in the ornamental trade (Goettsch et al. 2015).

The family Cactaceae is the fifth most threatened among large taxonomic groups; $31 \%$ of all species are threatened with extinction (Goettsch et al. 2015). The unscrupulous collection of live wild plants and seeds for the horticultural trade is considered one of the main drivers of extinction risk in the family, and it affects $47 \%$ of all threatened cacti (Goettsch et al. 2015). Therefore, the entire family (with the exception of Pereskia, Pereskiopsis, and Quabentia [27 species total]) is protected under CITES. However, in a study monitoring interactions between buyers and sellers of cacti on a single internet auction site, Sajeva et al. (2013) found that potentially legal trade was being conducted for only $10 \%$ of the species. Moreover, 57 cactus species (none of them listed as threatened) are now considered invasive around the world, all of which are thought to have been used for ornamental purposes (Novoa et al. 2015b). Several of these invaders are among the most common and widespread invasive species worldwide (Weber 2003) and negatively affect biodiversity, ecosystem functioning, resource availability, national economies, and human health (Novoa et al. 2016a).

This raises the question of whether the global horticultural trade of cactus species is compatible with conservation. We explored the need to regulate the international trade of ornamental cacti as it relates to overharvesting and biological invasions. We examined the global and South African situations. Hundreds of ornamental cactus species have been introduced to South Africa since the 18th century (Walters et al. 2011). Over time, the cactus horticultural trade in the country has developed into a substantial industry that is responsible for the exchange of hundreds of species every year. Some of these introductions have led to invasions across the country that have had substantial socioeconomic and environmental impacts, including harm to livestock, farmers, and biodiversity, and invasive cacti are listed as the most serious threat to biodiversity and human communities in arid regions of South Africa (Walters et al. 2011). Although the total cost of the impacts of cactus invasions in South Africa has not yet been quantified, nearly US\$6.7 million were spent by the government to control invasive cacti from 1995 to 2008 (van Wilgen et al. 2012). Despite this, more cactus species are being introduced and recorded as naturalized and are becoming invasive. Obermeyer (1976) reported only 12 cactus species in South Africa 40 years ago; 35 species are now considered naturalized (Walters et al. 2011).
Using the family Cactaceae as a case study, data from the CTD, the 11 largest international auction sites selling cacti on the internet, and all businesses involved in the cactus trade in South Africa, we addressed the following questions: does the international commercial horticultural trade contribute to the overharvest of threatened plant populations; is the commercial horticultural trade a main pathway for plant invasions; and what challenges are there to managing the international trade in ornamental plants sustainably?

\section{Methods}

\section{International Trade Recorded by CITES}

To examine aspects of the international trade in cactus species, we collated all records from the CTD (http://www.unep-wcmc-apps.org/citestrade/) of cacti traded from 1976 to 2014. We searched the CTD (trade.cites.org) by genus for the currently recognized 130 cacti genera and downloaded all records to identify the countries involved in the import and export of species, the number of trade records per country, the species traded, the products traded (live plants or seeds), the purpose (commercial, artificial propagation, personal, scientific, or botanical garden), and the source (artificially propagated or taken from the wild). We assigned importing and exporting countries to their respective continents and used data on the countries involved in the cactus trade and the number of trade records between continents to generate circos plots with the circlize package in $\mathrm{R}$ (version 3.0.2) (Galili et al. 2015). Because trade within the European Union does not require CITES permits, we could not account for exchanges among the 28 member states at either country or continent level. The lack of data on the exchanges among European countries did not affect our results for wild-collected threatened species because none of the threatened cactus species are native or have been recorded as naturalized or invasive in Europe (Novoa et al. 2014). However, it may have affected the results for invasive species.

Finally, using the information collated from the CTD, we compiled a list of ornamental cactus species being traded internationally, following the classification system developed by Novoa et al. (2015b). For each species, we noted its conservation (IUCN 2016) and invasion (as described by Novoa et al. [2015a]) status.

\section{International Online Trade}

Because e-commerce is a large and growing pathway for the global interchange of ornamentals that bypasses plant-trade regulations (Humair et al. 2015), we also explored the international horticultural trade of cactus species on the internet. We used Google to search for online cactus suppliers (search terms: cact* AND buy, 
cact* AND nursery, cact* AND online, cact* AND sale). For each search term, we examined the first 500 hits (based on relevance) and selected the 11 online nurseries trading internationally that had the largest variety of cactus species (Supporting Information). In February 2016, we recorded the names, appearance (we searched for characteristics associated with the plant being of wild origin [CITES Secretariat 2016]), and selling price of the species on sale at each online nursery and crosschecked the names against a standard nomenclature and lists of threatened (extinct, extinct in the wild, critically endangered, endangered, and vulnerable [IUCN 2016]) and invasive species (Novoa et al. 2015a). We also added eBay.com to our search because it is one of the world's largest online market places and its sellers are frequently engaged in the international trade (Humair et al. 2015).

\section{Nursery Trade in South Africa}

We identified plant nurseries selling ornamental cacti across South Africa with the assistance of traders, collectors, social media (Facebook groups), and local experts. We then visited the identified businesses and used a snowball sampling technique (Biernacki \& Waldorf 1981) to identify additional ones. Over 1 year (20132014), we conducted surveys with traders at all identified businesses.

The immediate objective of the surveys was to identify which cactus species were being sold in each nursery. It was not possible to reach this objective in most cases because most business owners did not know the identity of all their stock. Usually, pots and seed bags were labeled as cacti or cacti mix, and other succulent species were often mistakenly called cacti (Supporting Information).

We collected costumer profile information (owners of other nurseries, specialized collectors, or general public) and determined whether each business was importing cactus species, the approximate number of cactus species being sold $(<50,50-100,>100)$, and the identity, origin, and price of any cactus species they had imported. Finally, we ordered seeds of all cactus species recorded from the 1 surveyed importer.

\section{DNA Barcoding}

To test the accuracy of the identification of cactus taxa imported to South Africa, we placed seed samples in test tubes for subsequent DNA isolation and barcode analyses, which is a reliable, fast, and effective method to identify species (Janzen et al. 2009; Burgess et al. 2011). The use of short standardized gene regions can allow identification of unknown specimens to species level.

We performed DNA barcoding at the Canadian Centre for DNA Barcoding (CCDB) (University of Guelph) for each of the prepared seed samples. We used protocols modified from those of the CCDB (http://ccdb.ca/resources/). Specifically, we isolated the total genomic DNA from approximately 20 seeds per species with a semiautomated, membrane-based protocol (Ivanova et al. 2008). To homogenize the tissue, we added a small amount of sterile sand to each tube to allow better grinding of the plant seed by the TissueLyser (QIAGEN, the Netherlands). We then amplified the coding plastid regions ribulose-1,5-bisphosphate carboxylase $(r b c L)$, and maturase $\mathrm{K}$ (matK) with the primers rbcLaF/rbcLa-R and matK xF/matK-MALPR1, respectively (Supporting Information), as described in the protocols from the CCDB. These 2 regions are the approved and required standard regions for identifying land plants (von Cräutlein et al. 2011). We adapted the thermocycler program that amplifies the matK region as follows: initial denaturation at $99{ }^{\circ} \mathrm{C}$ for $45 \mathrm{~s}, 35$ cycles of $98^{\circ} \mathrm{C}$ for $10 \mathrm{~s}$, annealing at $52{ }^{\circ} \mathrm{C}$ for $30 \mathrm{~s}$, extension at $72{ }^{\circ} \mathrm{C}$ for $40 \mathrm{~s}$, and a final extension at $72{ }^{\circ} \mathrm{C}$ for $10 \mathrm{~min}$.

We visualized the PCR products on a $2 \%$ agarose gel with an E-Gel96 Pre-cast Agarose Electrophoresis System (Invitrogen, Carlsbad, CA, USA) and obtained the bidirectional sequences with the BigDye Terminator (version 3.1) Cycle Sequencing Kit (Applied Biosystems, Foster City, CA, USA) on an ABI 3730xL Genetic Analyzer (Applied Biosystems) (Hajibabaei et al. 2005). We assembled the obtained bidirectional sequences in SeqScape (version 2.1.1) (Applied Biosystems) and edited them manually. The edited sequences were used to perform BLAST searches with the NCBI BLAST (Johnson et al. 2008). For each BLAST search, we scored match success for both regions. An individual was scored as discriminated at the level of species or genus when there was a $100 \%$ similarity match with a single species or genus respectively for both regions. Finally, we compared the results with taxon names displayed on the labels provided by the importer.

\section{Results}

\section{International Trade Recorded by CITES}

Between 1976 and 2014, there were 129,512 CITES trade records for Cactaceae that involved 1,561 species in 100 genera (i.e., approximately $80 \%$ of all species and genera). The traded species included almost all known invasive species (51 out of 57) and over half ( 310 out of 516) of species considered threatened by the IUCN. However, over three-quarters of trade involved species that are neither invasive nor threatened (1200 species) (Fig. 1).

Most cacti were globally exchanged as live plants (79.0\%). Some were sold as seeds (19.0\%), mostly for commercial purposes (89.7\%), including all the species discussed above. Almost all trade records (97.8\%) reported that individuals were artificially propagated. Only $0.02 \%$ of all trade records were of plants taken from the wild (Supporting Information). 
(a) CITES

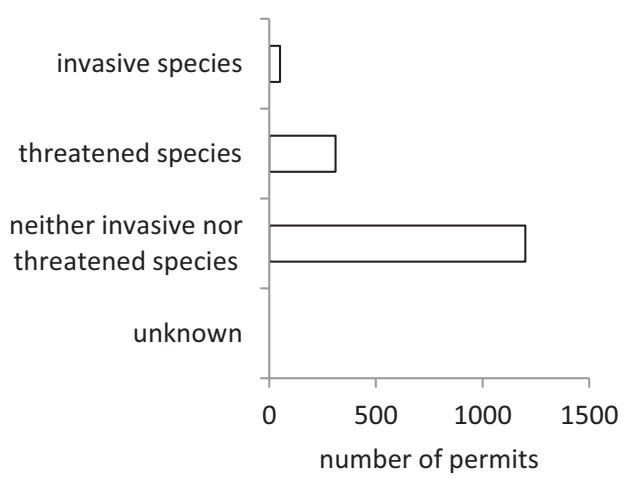

(c) Exports to South Africa

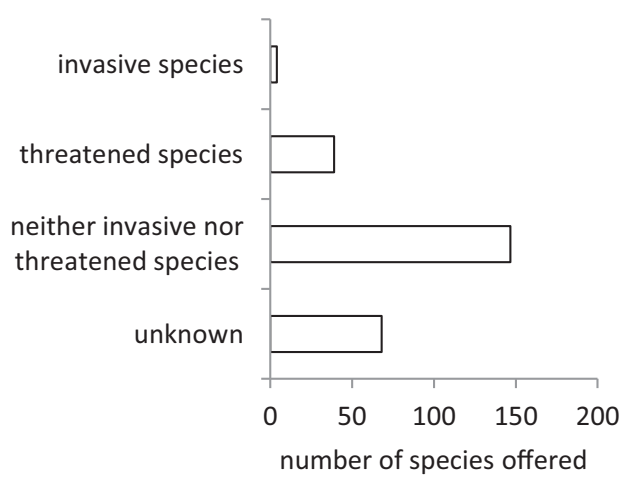

We found 118 exporting and 182 importing countries involved in the global exchange of cactus species (Fig. 2). Most exporters were in the United States (40.8\% of all trade records), the Netherlands (9.8\%), and Germany (8.7\%). Most importers were in Switzerland (14.3\%), the United States (10.5\%), and Germany (8.3\%). Overall, there was bidirectional exchange of cactus species between almost all continents (Fig. 3).

\section{Online Trade}

A total of 1525 species were on offer on the 11 selected websites. Most of the species overlapped with those recorded in CITES. However, we could not verify the names of $35.6 \%$ of the recorded species because they were listed as "cacti" or with common or nonexistent scientific names. We categorized these as unknown species. Among the verified names (982), 19 were of invasive taxa and 109 were of threatened taxa (Fig. 1). The selling price per individual plant of threatened, invasive, and neither invasive nor threatened cactus species all ranged from US\$0.80 to US\$60.

\section{Nursery Trade in South Africa}

We identified 70 nurseries as well as supermarkets, unofficial markets, and small retailers involved in the trade of cacti in South Africa. However, only 6 nurs-
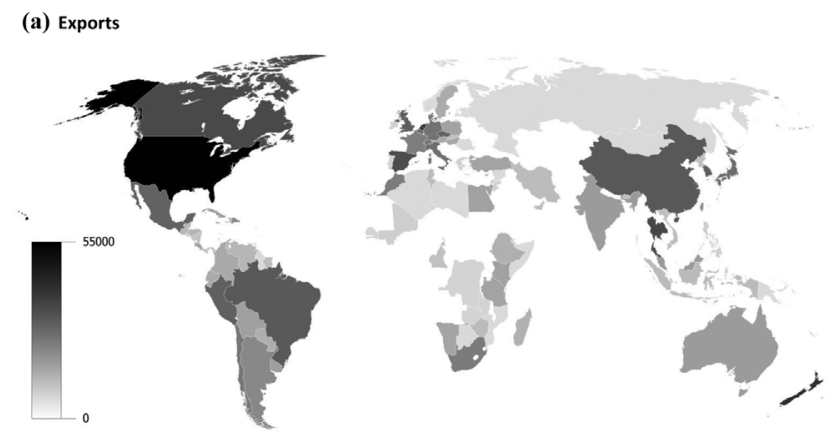

(b) Imports

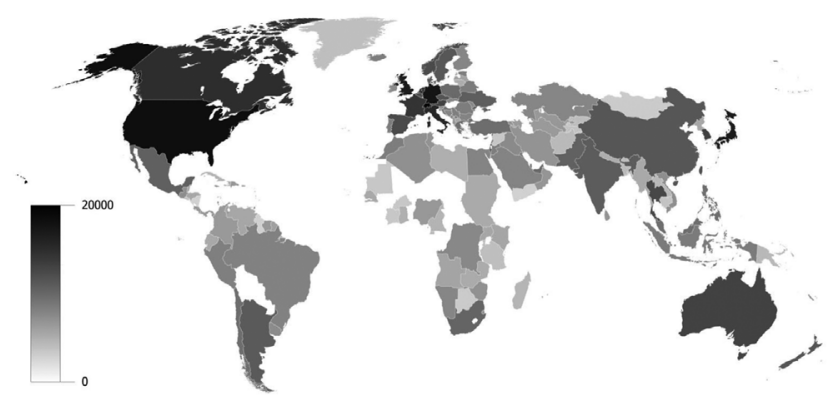

Figure 2. Worldwide number of records in the Convention on the International Trade in Endangered Species of Flora and Fauna Trade Database of (a) export and (b) import of cactus species from 1976 to 2014 . 


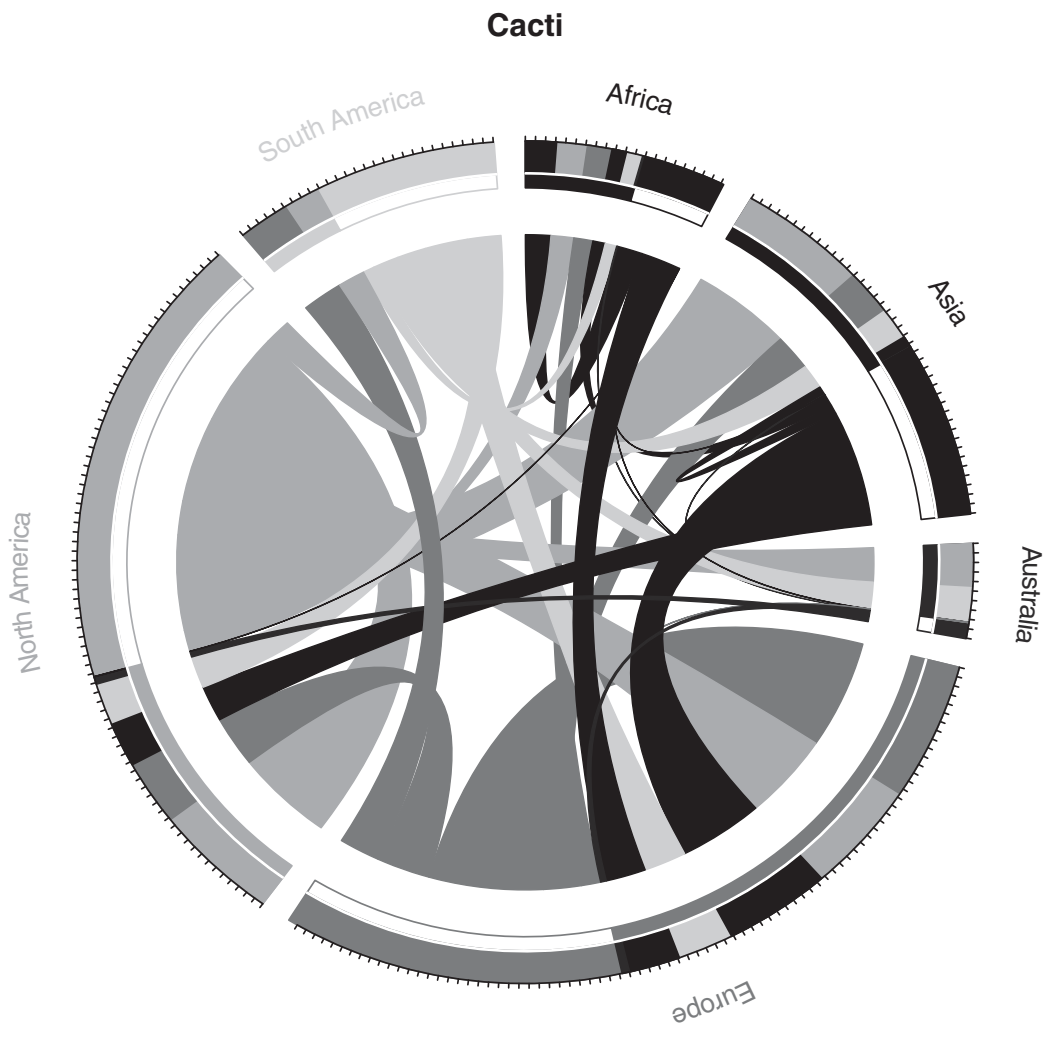

Figure 3. Exchange of cactus species between continents from 1976 to 2014 based on import-export records obtained from the Convention on the International Trade in Endangered Species of Flora and Fauna Trade Database (within the inner circle, white bars indicate export records; thin bars that are not white indicate import records). Internal trade within Europe is underestimated because within-EU trade is not listed in the database (i.e., the internal trade shown is only between $E U$ and non-EU countries).

eries were importing seeds of cactus species into South Africa (from which they grew their own plants and harvested their own seeds, thus creating their own stock). All cactus seeds were imported from a single source in Europe. All other horticultural businesses were buying their cacti from the six specialized nurseries (Supporting Information).

A total of 269 cactus species were imported to South Africa from 1988 to 2012, including 54 threatened species and 5 invasive species. Most species traded were neither invasive nor threatened (Supporting Information). Again, selling-price ranges for threatened, invasive, and neither invasive nor threatened species were similar. We contacted the European nursery that was exporting cacti seeds to South Africa in April 2014. There were 263 species for sale. All of the species (263) were from artificially propagated individuals (grown in culture by the nursery). We could not verify the names of 68 of the species because they were listed as "cacti" or with common or nonexistent scientific names. We categorized these as unknown species. Among the verified species, 4 (Cereus bildmannianus, Echinopsis schickendantzii, Echinopsis spachiana, and Myrtillocactus geometrizans) are invasive outside their native range (Novoa et al. 2015a), and 39 are threatened (Fig. 1).

\section{DNA Barcoding}

Of the species that did not have a valid name (68), we identified 18 to species and 39 to genus level. None of

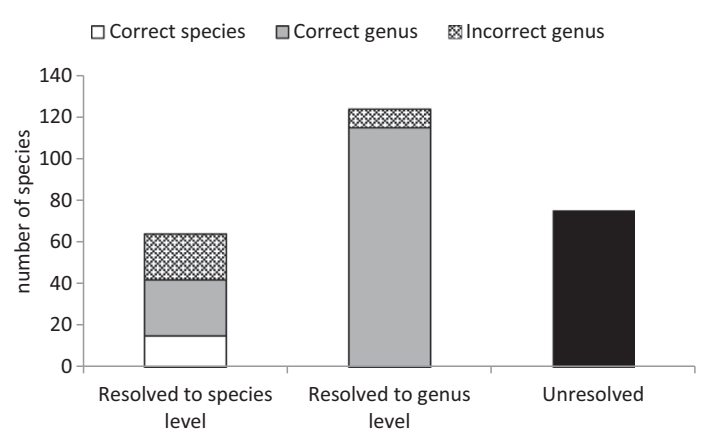

Figure 4. Results from the DNA barcoding of seeds to test the accuracy of plant labels used by the European nursery currently exporting cacti to Soutb Africa.

those were or contained invasive or threatened species. However, 11 species remained unidentified.

Of all analyzed species, we identified 64 to species level and 124 to genus level. However, the identity of 75 species was unresolved (Fig. 4), likely due to a lack of reference data on the GenBank online repository. Overall, only $59.7 \%$ and $5.7 \%$ of the species were adequately labeled to at least at the level of genus and species, respectively.

\section{Discussion}

The family Cactaceae contains many threatened (Goettsch et al. 2015) and many invasive species (Novoa 
et al. 2015a) and is one of the most popular horticultural plant groups worldwide (Anderson 2001). Almost all species ( $81 \%$ of total) were traded across many countries and many internet platforms. Although this may point to a complicated flow of trade, the South Africa example was remarkably simple. Nurseries imported all cacti from a single source, which had 263 cactus species on offer.

Our results suggest that, despite the extensive dissemination of hundreds of cactus species around the world and the overall threatened status of the group and a high incidence of invasiveness, few of the traded species are threatened or invasive (Fig. 1). This pattern seemed stable over time (Supporting Information), and there was no evidence of changes in global horticultural with regards to reliance on either threatened or invasive taxa.

The international horticultural industry appears to represent a threat through overharvesting only if traded individuals (or seeds) are unsustainably collected from the wild in their native range. However, we suspect that most of the threatened cacti that are currently traded come from artificially propagated individuals and therefore are not collected from wild populations, at least by the largest commercial companies. Approximately $98 \%$ of the records from the CTD were reported as artificially propagated individuals. All seeds imported to South Africa also came from artificially propagated individuals. Although it is difficult to prove definitively whether an individual is sourced from the wild or from artificial propagation (Retief et al. 2014), there are often morphological indicators (e.g., plants collected from the wild tend to be much less symmetrical). The cacti traded on the international internet auction sites we investigated did not appear to be of wild origin (i.e., they were healthy looking plants with uniform spines). Sajeva et al. (2013) also observed this when they monitored a single auction site selling cacti online. Therefore, we do not expect the international horticultural trade in cactus species to have major effects on wild populations. However, the local horticultural trade of threatened cactus species in their native range remains to be investigated, and illicit traders would not have been identified by our analysis. It is also important to determine whether trade will remain based almost exclusively on artificially propagated material.

The horticultural trade is a major pathway for the spread of invasive species (Mack 2000; Reichard \& White 2001; Pyšek et al. 2002; Kowarik 2005), and this could be the case for Cactaceae as well. Although invasive species formed only a small fraction of all traded cacti, we found 51 of the 57 invasive cactus species (sensu Novoa et al. $2015 a$ ) in trade records in the CTD. Moreover, 19 invasive species are being sold online on different internet auction sites. In South Africa, however, we found only one invasive cactus species being imported to the country.

Because cactus invasions can cause a wide variety of negative environmental and socioeconomic impacts (Novoa et al. 2016a), we believe the global trade of inva- sive cacti should be regulated (i.e., by identifying and intercepting invasive and potentially invasive species) with the aim of preventing future invasions. Because invasive cacti constitute only a small fraction of all internationally traded cacti, prevention efforts will not result in substantial restriction of commercial activities. Moreover, invasions are context specific (i.e., invasiveness materializes only when certain environmental requirements are met) (Hayes \& Barry 2008). This means not all species recorded as invasive or potentially invasive will invade all areas of the world. A challenge is to identify which taxa are likely to be invasive under which conditions. Species distribution models provide the means for identifying areas that are climatically suitable (and therefore potentially invasible) for particular ornamental plants (e.g., Dullinger et al. 2016) and are routinely used in risk assessment for invasiveness (Kumschick \& Richardson 2013).

A critical aspect of regulating the global trade to prevent future invasions is the ability to accurately identify, detect, and intercept species at the ports of entry (Armstrong \& Ball 2005). Species identification is particularly challenging for cacti. There is instability in nomenclature within the family, probably due to inconsistencies in previous taxonomies and poor representation of cacti in herbariums. Their succulence and spines make them difficult to collect and curate (Walters et al. 2011). Moreover, flowers and fruits are often necessary for species identification, but cacti may go years without flowering (Anderson 2001). Therefore, cactus species are often found in the literature and nursery trade under incorrect (as a consequence of changes in taxonomy or misidentification) or even fictitious scientific or common names. Accordingly, we could not verify $35.6 \%$ of the species sold on the 11 explored international internet auction sites or $25.9 \%$ of the 263 species sold by the only nonSouth African nursery that was exporting cactus species to South Africa. Even among the verified species, it was challenging to verify the species names to obtain currently accepted species, and we expect that some errors may be present, as well as some points of taxonomic disagreement in the verified names. Moreover, in the nonSouth African nursery exporting cacti to South Africa, only $5.7 \%$ of the 263 species were labeled correctly. The original seed collection of most of such species was done more than 50 years ago. All cacti were morphologically identified (often without access to flowers or fruits) based on field guides, which probably led to the use of outdated or incorrect scientific or common names.

In groups with identification difficulties and nomenclature instability, DNA barcoding provides a promising tool (Dunning \& Savolainen 2010); we identified 71.5\% of the 263 species at least to genus level. However, there are many challenges associated with DNA barcoding, especially for plants (Valentini et al. 2009). It requires large capacity and funding and, as shown by our results, target organisms cannot always be identified to species 
or genus level due to gene conservatism (Will \& Rubinoff 2004). There are several other supplementary DNA barcoding regions that could be used when an organism cannot be identified using the standard matK and $r b c L$ regions (Hollingsworth et al. 2011). For example, the intergenic spacer $t r n H-p s b A$ has been successfully used as a supplementary barcode in several studies (e.g., Quercus [Piredda et al. 2011] and Alnus [Ren et al. 2010]). However, even the use of such supplementary barcodes does not guarantee identification success and would require more capacity and funding (von Cräutlein et al. 2011). An alternative for cacti is the use of seed size and mass for identifying invasive species at ports of entry; most invasive cacti have substantially larger and heavier seeds than non-invasive cacti (Novoa et al. 2016c). Although in South Africa all introductions of cactus species are in the form of seeds, cacti are being interchanged all over the world as both live plants and seeds (79\% of the records from the CTD are of live plants). In cases where cacti are imported as plants, invasive cacti may be identified by growth form. Unlike most plant groups, invasiveness in cacti is strongly correlated with particular growth forms (Novoa et al. 2015a). However, as phenotypical identification will likely not always be sufficient, it is important that an appropriate DNA barcoding technique for Cactaceae be developed.

Prevention efforts also require engagement with the businesses importing and selling invasive plants and an understanding of their willingness to accept regulation of the trade of invasive species (Novoa et al. 2016b; Supporting Information). Most recent efforts to prevent the use of invasive ornamentals are focused on voluntary self-regulation of the horticultural trade (Burt et al. 2007) (e.g., the St Louis Declaration and Voluntary Codes of Conduct [Baskin 2002] or the Code of Conduct on Horticulture and Invasive Plants [Heywood \& Brunel 2008]). Codes of conduct encourage nursery professionals to participate in preventive measures such as identifying alternatives to invasive plants or ceasing to stock invasive plants or make them available. Due to the small percentage of invaders among all internationally traded cacti, we believe horticultural cactus traders would easily adopt these preventive measures. If traders engage with these voluntary codes of conduct and if restrictions are placed on the small proportion of cacti that are invasive, the commercial cactus horticultural trade will pose a negligible environmental threat. The threat from person-to-person trade and illegal collectors, however, still needs to be quantified.

By assessing the environmental risks of a major taxonomic group of ornamental plants, we highlighted the importance of artificial propagation, correct species identification, and engagement with stakeholders to reduce the environmental threat of the commercial horticultural trade.

\section{Acknowledgments}

We thank all stakeholders for their participation and M. Koordom and V. Visser for their help. Funding for this work was provided by the Working for Water (WfW) Programme of the South African Department of Environmental Affairs, through the South African National Biodiversity Institute Invasive Species Programme (SANBI ISP), and through the DST-NRF Centre of Excellence for Invasion Biology $(C \cdot I \cdot B$ ) (as part of the $C \cdot I \cdot B / W f W$ collaborative research program Research for Integrated Management of Invasive Alien Species). We acknowledge additional support from the National Research Foundation (grant no. 85417 to D.M.R.).

\section{Supporting Information}

Online nurseries trading cactus species internationally (Appendix S1); photos of plant labels in the nursery trade of succulent species in South Africa by Ana Novoa (Appendix S2); primer sequences for the 2 plastid genomic regions (Appendix S3); data extracted from the CTD (Appendix S4); distribution of the 70 plant nurseries selling cactus species in South Africa (Appendix S5); percentage of invasive, threatened, and neither invasive nor threatened cactus species recorded in the permits issued by CITES and imported to South Africa (Appendix S6); number of trade records in the permits issued by CITES and seed introductions to South Africa for invasive, threatened, and neither invasive nor threatened cactus species (Appendix 57); and descriptions of existing collaborations between the authors and the cactus horticulturists in South Africa (Appendix S8) are available online. The authors are solely responsible for the content and functionality of these materials. Queries (other than absence of the material) should be directed to the corresponding author.

\section{Literature Cited}

Anderson EF. 2001. The cactus family. Timber Press, Portland, Oregon. Anderson NO, Galatowitsch SM, Gomez N. 2006. Selection strategies to reduce invasive potential in introduced plants. Euphytica 148:203216.

Armstrong KF, Ball SL. 2005. DNA barcodes for biosecurity: invasive species identification. Philosophical Transactions of the Royal Society B: Biological Sciences 360:1813-1823.

Baskin Y. 2002. The greening of horticulture: new codes of conduct aim to curb plant invasions. BioScience 52:464-471.

Barthlott W, Hunt DR. 1993. Cactaceae. Pages 161-197 in Kubitzki K, editor. The families and genera of vascular plants. Vol. II. Springer, Germany.

Biernacki P, Waldorf D. 1981. Snowball sampling: Problems and techniques of chain referral sampling. Sociological methods \& research 10:141-163.

Burgess KS, Fazekas AJ, Kesanakurti PR, Graham SW, Husband BC, Newmaster SG, Percy DM, Hajibabaei M, Barrett SC. 2011. Discriminating 
plant species in a local temperate flora using the rbcL+ matK DNA barcode. Methods in Ecology and Evolution 2:333-340.

Burt JW, Muir AA, Piovia-Scott J, Veblen KE, Chang AL, Grossman JD, Weiskel HW. 2007. Preventing horticultural introductions of invasive plants: potential efficacy of voluntary initiatives. Biological Invasions 9:909-923.

Callaway DJ, Callaway MB. 2000. Breeding ornamental plants. Timber Press, Portland.

CITES (Convention on International Trade in Endangered Species of Wild Flora and Fauna) Secretariat. 2016. Differentiating wildcollected and artificially-propagated plants. CITES Secretariat, Genva. Available from https://cites.unia.es/file.php/1/trainers/ E-GC\%20Briefcase-08.ppt (accessed January 2016).

Clement EJ, Foster MC. 1994. Alien plants of the British Isles. Botanical Society of the British Isles, London.

Dehnen-Schmutz K, Touza J. 2008. Plant invasions and ornamental horticulture: pathway, propagule pressure and the legal framework. Floriculture, Ornamental and Plant Biotechnology 5:15-21.

Dehnen-Schmutz K, Touza J, Perrings C, Williamson M. 2007a. A century of the ornamental plant trade and its impact on invasion success. Diversity and Distributions 13:527-534.

Dehnen-Schmutz K, Touza J, Perrings C, Williamson M. 2007b. The horticultural trade and ornamental plant invasions in Britain. Conservation Biology 21:224-231.

Dunning LT, Savolainen V. 2010. Broad-scale amplification of matK for DNA barcoding plants, a technical note. Botanical Journal of the Linnean Society 164:1-9.

Dullinger I, et al. 2016. Climate change will increase the naturalization risk from garden plants in Europe. Global Ecology and Biogeography 26:43-53.

Ewan J. 1969. A short history of botany in the United States. Hafner Publishing, New York.

Galili T, Simpson G, Jefferis G, Gallotta M, Renaudie J, Hornik K, Ligges U, Spiess AN. 2015. dendextend: an R package for visualizing, adjusting and comparing trees of hierarchical clustering. Bioinformatics 31:3718-3720.

Goettsch B, et al. 2015. High proportion of cactus species threatened with extinction. Nature Plants 1:15142.

Hajibabaei M, Ivanova NV, Ratnasingham S, Dooh RT, Kirk SL, Mackie PM, Hebert PD. 2005. Critical factors for assembling a high volume of DNA barcodes. Philosophical Transactions of the Royal Society of London B: Biological Sciences 360:1959-67.

Hayes KR, Barry SC. 2008. Are there any consistent predictors of invasion success? Biological Invasions 10:483-506.

Heywood V. 2001. Conservation and sustainable use of wild species as sources of new ornamentals. Pages 43-53 in Düzyaman E, Tüzel Y, editors. ISHS Acta Horticulturae 598: International Symposium on Sustainable Use of Plant Biodiversity to Promote New Opportunities for Horticultural Production Development. International Society for Horticultural Science, Leuven, Belgium.

Heywood V, Brunel S. 2008. Code of conduct on horticulture and invasive alien plants. Convention on the conservation of European wildlife and natural habitats, Standing Committee.

Hollingsworth PM, Graham SW, Little DP. 2011. Choosing and using a plant DNA barcode. PloS ONE 6:e19254.

Howard RA, Touw M. 1981. The cacti of the Lesser Antilles and the typification of the genus Opuntia Miller. Cactus and Succulent Journal 53:233-237.

Humair F, Humair L, Kuhn F, Kueffer C. 2015. E-commerce trade in invasive plants. Conservation Biology 29:1658-1665.

International Union for Conservation of Nature and Natural Resources (IUCN). 2016. IUCN Red List, Gland, Switzerland. Available from www.iucnredlist.org/ (accessed January 2016).

Ivanova NV, Fazekas AJ, Hebert PD. 2008. Semi-automated, membranebased protocol for DNA isolation from plants. Plant Molecular Biology Reporter 26:186.
Janzen DH, et al. 2009. Integration of DNA barcoding into an ongoing inventory of complex tropical biodiversity. Molecular Ecology Resources 1:1-26.

Johnson M, Zaretskaya I, Raytselis Y, Merezhuk Y, McGinnis S, Madden TL. 2008. NCBI BLAST: a better web interface. Nucleic acids research 36:5-9.

Kowarik I. 2005. Urban ornamentals escaped from cultivation. Pages 97-121 in Gressel J, editor. Crop fatality and volunteerism. CRC Press, Boca Raton, Florida.

Kumschick S, Richardson DM. 2013. Species-based risk assessments for biological invasions: advances and challenges. Diversity and Distributions 19: 1095-1105.

Lockwood JL, Cassey P, Blackburn T. 2005. The role of propagule pressure in explaining species invasions. Trends in Ecology \& Evolution 20:223-228.

Mack RN. 2000. Cultivation fosters plant naturalization by reducing environmental stochasticity. Biological Invasions 2:111-122.

Niemiera AX, Von Holle B. 2009. Invasive plant species and the ornamental horticulture industry. Pages $167-187$ in Management of invasive weeds. Springer, the Netherlands.

Novoa, A, González, L. 2014. Impacts of Carpobrotus edulis (L.) NE $\mathrm{Br}$. on the germination, establishment and survival of native plants: a clue for assessing itscompetitive strength. PLOS ONE 9:e107557 https://doi.org/10.1371/journal.pone.0107557.

Novoa A, Le Roux JJ, Robertson MP, Wilson JR, Richardson DM. 2014. Introduced and invasive cactus species-a global review. AoB Plants 3:plu078.

Novoa A, Le Roux JJ, Robertson MP, Wilson JRU, Richardson DM. $2015 a$. Introduced and invasive cactus species-a global review. AoB Plants 7 (plu078) https://doi.org/10.1093/aobpla/plu078.

Novoa A, Kaplan H, Kumschick S, Wilson JRU, Richardson DM. $2015 b$. Soft touch or heavy hand? Legislative approaches for preventing invasions: insights from Cacti in South Africa. Invasive Plant Science and Management 8:307-316.

Novoa A, Kumschick S, Richardson DM, Wilson JRU. 2016a. Native range size and growth form in Cactaceae predicts invasiveness and impact. Neobiota 30:75-90.

Novoa A, Kaplan H, Wilson JRU, Richardson DM. 2016b. Resolving a prickly situation: involving stakeholders in invasive cactus management in South Africa. Environmental Management 57:998-1008.

Novoa A, Rodríguez J, López-Nogueira A, Richardson DM, González L. 2016c. Seed characteristics in Cactaceae: Useful diagnostic features for screening species for invasiveness? South African Journal of Botany 105:61-65.

Obermeyer AA. 1976. Cactaceae. Pages 144-156 in Ross JH, editor. Flora of Southern Africa. Botanical Research Institute, Pretoria.

Phelps J, Webb EL. 2015. "Invisible" wildlife trades: Southeast Asia's undocumented illegal trade in wild ornamental plants. Biological Conservation 186:296-305.

Piredda R, Simeone MC, Attimonelli M, Bellarosa R, Schirone B. 2011. Prospects of barcoding the Italian wild dendroflora: oaks reveal severe limitations to tracking species identity. Molecular Ecology Resources 11:72-83.

Pyšek P, Sadlo J, Mandak B. 2002. Catalogue of alien plants of the Czech Republic. Preslia 74:97-186.

Reeve R. 2014. Policing international trade in endangered species: the CITES treaty and compliance. Earthscan Publications, London.

Reichard SH, White P. 2001. Horticulture as a pathway of invasive plant introductions in the United States. BioScience 51:103-113.

Ren BQ, Xiang XG, Chen ZD. 2010. Species identification of Alnus (Betulaceae) using nrDNA and cpDNA genetic markers. Molecular Ecology Resources 10:594-605.

Retief K, West AG, Pfab MF. 2014. Can stable isotopes and radiocarbon dating provide a forensic solution for curbing illegal harvesting of threatened cycads? Journal of Forensic Sciences 59:1541-1551.

Sajeva M, Augugliaro C, Smith MJ, Oddo E. 2013. Regulating internet trade in CITES species. Conservation Biology 27:429-430. 
Seaton K, Bettin A, Grüneberg H. 2014. New ornamental plants for horticulture. Pages 435-463 in Dixon GR, Aldous DE, editors. Horticulture: plants for people and places. Vol. 1. Springer, the Netherlands.

Sharma GP, Raghubanshi AS, Singh JS. 2005. Lantana invasion: an overview. Weed Biology and Management 5:157-165.

Van Wilgen BW, Forsyth GG, Le Maitre DC, Wannenburgh A, Kotzé JDF, van den Berg E, Henderson L. 2012. An assessment of the effectiveness of a large, national-scale invasive alien plant control strategy in South Africa. Biological Conservation 148:2838.

Villamagna AM, Murphy BR. 2010. Ecological and socio-economic impacts of invasive water hyacinth (Eichhornia crassipes): a review. Freshwater Biology 55:282-298.

von Cräutlein M, Korpelainen H, Pietiläinen M, Rikkinen J. 2011. DNA barcoding: a tool for improved taxon identification and detection of species diversity. Biodiversity and Conservation. 20:373389.
Walters M, Figueiredo E, Crouch NR, Winter PJD, Smith GF, Zimmermann HG, Mashope BK. 2011. Naturalised and invasive succulents of southern Africa. Abc taxa. Vol. 11. Belgium Development Corporation, Brussels.

Weber E. 2003. Invasive plant species of the world: a reference guide to environmental weeds. CABI publishing, United Kingdom.

Will KW, Rubinoff D. 2004. Myth of the molecule: DNA barcodes for species cannot replace morphology for identification and classification. Cladistics 20:47-55.

Winter JHS, Botha DJ. 1994. The release of endangered plants into the horticultural trade: Conservation or exploitation? Biodiversity and Conservation 3:142-147.

Wyman D. 1968. The introduction of plants from Europe to America. Pages 12-16 in Manks DS, editor. Origins of American horticulture: a handbook. Brooklyn Botanic Garden, New York.

Zhou WZ. 1994. The role of horticulture in human history and culture. Horticulture in Human Life, Culture and Environment 391:41-52.

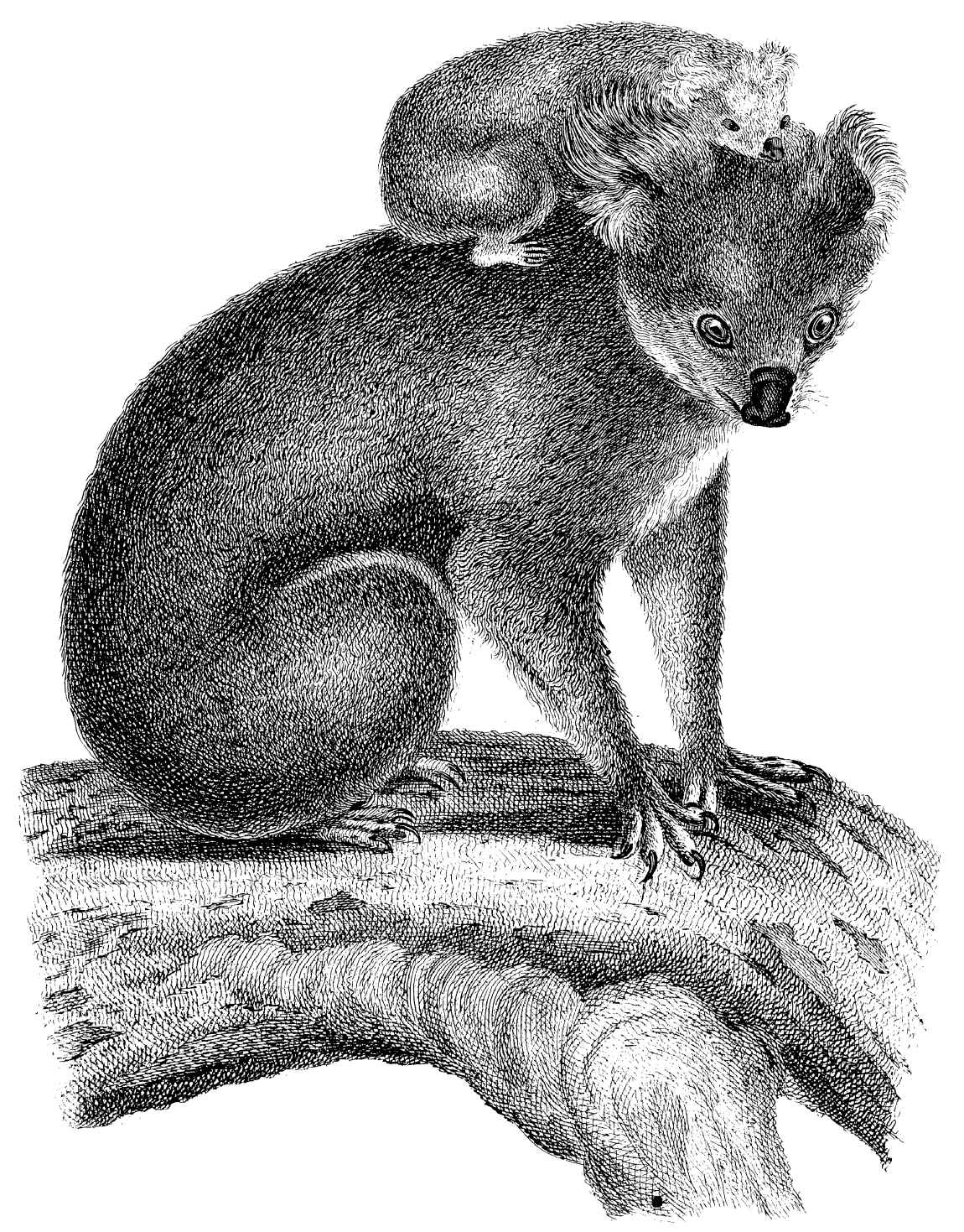

